\title{
The Influencing Factors of Voters' Level of Participation of Regional Head Election in Pekanbaru City 2017
}

\author{
Data Wardana \\ Lecturer in Government Science Islamic University of Riau \\ Datawardana17@gmail.com
}

\begin{abstract}
Indonesia is one of the world's most democratic countries. In this understanding, the people have a very important position because sovereignty is in the hands of the people. This means that the people are sovereign, the powerful to determine the way in which they should be governed. Implementation of general elections, as well as elections to the general quality of the region, is needed as a means to realize the sovereignty of the people. Therefore, public participation is needed for the implementation of the regional elections of heads of quality and get legitimacy from the people. One of the regions conducting the election of regional heads in 2017 is Pekanbaru City. However, the participation of the public is only 285.787 from 572.029 Permanent Voter List or with the percentage of $\mathbf{5 0 . 2 5}$ percent. This paper presents what are the factors that influence the level of voter participation in the election of the regional head of Pekanbaru City in 2017. The research methods used to answer the above problems is the qualitative method with the data collection techniques are observation, interview, and documentation. Us for the informal is Pekanbaru City Election Commission, Pekanbaru City Election Supervisory Committee and Society who have the right to vote. The factors that influence the level of community participation are the first candidate figure, the two emotional closeness of one region with candidate and money politic or transactional politics and socialization conducted by organizer general election.
\end{abstract}

Keywords: Community Participation, Regional Head Election, Pekanbaru City.

\section{INTRODUCTION}

As the State's democratic elections are the embodiment of popular sovereignty. People give his power to its representatives in the Government to govern and oversee the organization Government to conform to the rules that are made to enhance the welfare of society. Besides the general election as well as a means of political participation of the community and the place of channeling the aspirations of politics. It is hoped the people through its representatives can run in government function supervision with either for the benefit of the people and the partiality to the people. Because people which give his power to mandate the Government to run the country according to the purpose of the unity of the Republic of Indonesia that is contained in the preamble of the Constitution of 1945. Therefore, the election is an important means for receiving a mandate from the people to its representatives in government. For it needs to create a quality elections, with election to increase the implementation promotes public participation.
Participating in the elections is a form of political participation at least citizens. Through citizen, elections choose representatives who will sit in the representative institutions. But the quality of the implementation of the general election is also inseparable from the organizer's elections, namely Electoral Commission. To carry out the elections formed the election organizers are set forth in the Act. Organizers of the elections is the agency that organizes elections comprised Elections Commission and directed the Agency's Election as one function of organizing elections to choose members of the House of representatives, the regional representative Council, The House of representatives region, President and Vice President directly by the people, as well as to select Governors, Regents and mayors democratically. In the modern political analysis of political participation is an important issue, and lately many are studied primarily in developing countries. Political participation the better be seen increasing public participation in political activities. The existence of a caring community in giving his political aspirations in a democratic agenda. The development of democracy gave rise to many community groups that want to influence the public policy decision-making process.

For organizing election is formed Election Commission up to the central level called the provincial KPU, called KPU at the level of provinces and district/city referred to the county town, sub-district called PPK to the village level is called the PPS. Who each have duties, authority, and responsibilities under the Act. Almost all over the country that has Democracy become Election in the part instrument to choose leaders who will live the wheels of Government. On 17 February 2017 Indonesia carry out districts elections simultaneously, one of which is the city of Pekanbaru. However, the level of participation voters in the election exercise his right belongs to the low this looks from the turnout with the right pilihnya just 285,787 based on the results of the plenary meeting of the General Election Commission city of Pekanbaru Wednesday, February 22, 2017. While the list of Voters Remain 572,029 (source, results of the General Election Commission assignment Pekanbaru Monday 5 December 2017.

The general election the head of the regional city of Pekanbaru followed by five pairs of candidates two of them independent candidates or individuals. For a candidate, the individual must attach support According the rules already established, the minimum amount of support that should be 
retrieved as many as 47,041, "said Commissioner of the KPU Pekanbaru Mai Andri told reporters after the plenary convenes open attended Commissioner of the KPU and the 12-person Election Committee Sub-district (PPK), Thursday (20/10/2016). The city of Pekanbaru announced two pairs of Prospective Candidates (Baspalon) of the individual lines, Herman NazarDevi Warman and Syahril-Said Zohrin was declared Eligible in terms of stage of the election Districts (Elections) Pekanbaru 2017. From the results of the recapitulation in Pekanbaru against the Individual, spouse support Syahril-Said Zohrin managed collect 47,137 copy of ID CARD ( KTP ) support. Meanwhile, Herman Nazar-Deviwarman collect 50,251 copy of ID CARD ( KTP ) support. With the amount of support obtained both individual pairs of candidates is specified as the contestants who are competing in the elections of mayors and Deputy mayors of Pekanbaru year 2017.

The political Wherewithal to manifest the will of the people to the State in the system of Pancasila Democracy is Elections (Pemilu). The people's sovereignty as the holder has the right to determine the color and form of Government as well as goals to be achieved, in accordance with the Constitution. But the level of participation of the high society gives support to independent candidate turns out to be not worth the election results it can be seen from obtaining the results of each candidate that is. Based on election commission (KPU) Plenary meeting of Pekanbaru Electoral (KPU) plenary meeting to held the city of Pekanbaru on recap of the calculation result Tally the votes and the results of the election of mayors and Deputy-mayors of Pekambaru, at the Hotel Aryadutha, Pekanbaru, Wednesday, February 22, 2017. At the plenary Chairman election commission (KPU) led by Amiruddin Sijaya decided, candidate pair from your order 3 the winner of the elections Pekanbaru 2017 by obtaining 94,784 votes. Then, in a second vote, the position occupied by candidate pair number sort 5 Dastrayani Bibra-Said Usman Abdullah with the acquisition of candidate pair, followed by the numbers of 62,501 number sort 4 Ramli Walid-Roger Herman with the acquisition numbers of 59,694. While in ordinal numbers underneath independent couples two Herman Nazar-Devi Warman with 46,606 numbers and the last pair number sort 1 Syahril-Said Zohirin with 22,202 votes. The number of valid 285,787 votes or by percentage of 50.25 percent. Thus it can be indicated that the low voter participation belongs to transmit the right to vote on the electoral districts in the city of Pekabaru. Therefore, need to know what factors affect the level of public participation in the concurrent regional head election 2017 in Pekanbaru City.

\section{THE STUDY OF THEORY}

\section{Theory Of Power}

According to Max Weber's power is the chance of a person or group of people to arouse the society will accord yourself with his/her preferences at once applied it towards actiontinakan resistance from people or groups-groups certain according to Samuel h. Beer and Adam b. Ulam design. Taerdapat the four variables in the political system:
1. Power - as a way to achieve the desired, among other sources divide between community groups

2. Interest - the goals pursued by the perpetrator-perpetrators or political groups

3. Wisdom-the result of interaction between power and interests, usually in the form of legislation

4. Political culture - the subjective orientation of the individual against the political system.

The opinion of Max power with regard to how to achieve the desired goals. According to Gary Yukl power is a dynamic variable variable has changed along with the change in conditions. How power is used and the results of efforts affect can increase or drop the powers of an agent. Powers explains the absolute capacity of an agent that affects behavior or attitude of someone or more is designated as a target at a given time.

According to Weber Power is ability to, and a social relationships, carry out their own accord even if experiencing any resistance, and the basis of this ability. Academics who is roughly the same with that in mind it is Harold d. Laswell and Abraham Kaplan, the definition has already become a classic formulation; Power is a relationship someone or a group of people can determine one's actions or other groups towards the goal of the 1st century. From some expert opinion can be summed up the power is a person's ability to influence the behaviour of others according to what you want.

\section{The Theory Of Democracy}

According to H. Harris Soche democracy is the form of Government of the people, because the power that Government attaches to people's self or self crowds and is right for the people or the people to set up, maintain and protect itself from coercion and rape by another person or body that is entrusted to govern. According to C.F. players Strong democracy is a system of Government in which the majority of the Board members of the community participate in politics on the basis of a system of representation that guarantees the Government finally charged his actions on the majority of them. Democracy developed as a means to absorb, hold and carry out the aspirations of the community. As a simple understanding of democracy, namely the Government of the people, by the people and for the people. Democracy set up how freedom of speech, conveying the aspirations, speak also of freedom of Association in accordance with the provisions in force. Through the election, the public can limit the powers of government, because the election was carried out as a form of manifestation of democracy without intimidation from the wherever.

\section{The Theory Of Political Participation}

The development of democracy gave rise to many community groups that want to influence the public policy decision-making process. Public defenition as that political participation is an activity of a person or group of people to participate actively in political life, such roads with select State and leader, directly and indirectly, affect Government policy (public policy). Charles Andrian and James Smith in the three forms of participation classify Marijan's House. The first is a more passive participation. In the first type, the participation of political involvement as seen from someone, namely the extent to which that person is seeing politics as something important, 
have interest in politics, and frequent discussions about political issues with friends. The second more active participation. Of concern is the extent to which the person is involved in organizations or voluntary associations such as religious groups, sports, lovers of the environment, professional organizations, and labor organizations. Political participation is the third form of protest activities like join signed a petition, boycott, and demonstrations. This is supported by the opinion of Miriam Budiardjo talk about political participation that participation is the activity of a person or group of people to actively participate in political life that is by the way select the leadership directly and not directly affecting government policy (public policy) covers the Act of voting in the general election.

\section{METHODOLOGY}

The Research is a thing that is very important in solving a problem. The research has a method to facilitate problem resolution. According to Ndraha methods can be defined as the way (the way, approach, tools) that should be taken (used) in order to gain knowledge about a thing (target study), whether past, present, and to come: happening and will happen. In this study using qualitative descriptive method with illustrates and explain the results of the research with the problems relating to the factors that affect turnout. According to Djam'an Satori and qualitative research Komariah Aan is an approach to research that reveals the particular social situation by describing the reality heard right, formed by the words based on collection and analysis techniques the relevant data obtained from the natural situation. Strauss and Corbin 1997 in Basrowi And Suwandi is the kind of research that produces inventions that cannot be achieved using statistical procedures or by other quantification. The research of qualitative can be used to examine the life of community, history, behavior, social engineering, organization, movement or kinship. Bodgan and Taylor 1992 stated that qualitative research is one of the research procedures that produce descriptive data in the form of speech or writing and the behavior of people who observed. The author describes the actual circumstances in detail see the problem and research objectives. Descriptive research can be defined as the process of problem solving is investigated with a painted State of subjects and research on the present moment based on the facts that looked or how it is. So on to be analyzed and drawn conclusions. As for the becoming informen in this research is the city Electoral Commission Election Committee in Soweto, the city of Pekanbaru, successful Candidate Team and community. With the techniques of data collection in field observations is viewed and observed the stages of implementation of the general election, the head of the regional city of Pekanbaru. Then conduct interviews with selected with informen informen a samplin Purvosive disampel as well as the required documentation by taking the berkaiotan with the implementation of the selection and participation of the people.

\section{STUDY OF ANALYSIS}

The election of the head of the area directly is a means of manifestation of political participation of the community. One of its shape with join make and give the right sound. The opinion of Michel Rush and Philip Althoff which argues that political participation forms commonly known is the granting of the vote (voting). Voting is a political participation that does not require much effort. This activity is carried out at a time when it is needed. Based on the results of research conducted can be aware that factors that influence the turnout rate in the elections of mayors and heads of regional Deputy Mayor of Soweto year 2017 is

\section{The figure of the candidate for Mayor and Vice-mayor.}

The factors that give the role is that politics is the perception of a person against the object namely figurines, programs and interests. If candidates participated in the elections did not correspond to the criteria of the desired figure, the passive community or not participate in channeling their rights. In the elections of mayors and Deputy mayors of Pekanbaru on follow by five pairs of candidates. The candidate is composed from three (3) candidates who carried out by political parties and two candidates from individual members. As for 5 (five) candidates, candidate number sort 1 Syahril-Said Zohirin with 22,202 votes, numbers sort Herman Nazar-Devi Warman with 46,606 votes, candidates from your order 3 the winner of the elections Pekanbaru 2017 by obtaining 94,784 votes, candidate number sort 4 Ramli Walid-Roger Herman with the acquisition of numbers and last 59,694 candidate number sort 5 Dastrayani Bibra-Said Usman Abdullah with the acquisition of a sound source, 62,501 based on the plenary meeting of the Pekanbaru Electoral (KPU) plenary meeting to held the city of Pekanbaru on recap of the calculation result Tally the votes and the results of the election of mayors and Deputy-mayors of Pekanbaru, at the Hotel Aryadutha, Pekanbaru, Wednesday February 22, 2017. From the sound acquisition candidate number sort of three (3) or incumbent candidate re-elected to serve mayors and Deputy mayors of Pekanbaru 2017-2022 Period. Prospective figures factor is the factor that determines the level of the participation of voters in the city of Pekanbaru. Based on the results of interviews with the community which is informen participate with voting rights as well as the community that includes the list of voters remain but are not using the right to vote. The results of the interviews can be noted that the level of satisfaction of the people against the incumbent candidate's figures as well as other candidates who have not been so identified so that community voters city of Pekanbaru is very difficult to determine the choice and be the reason for not choose either the right or the right of vote. In addition to this the reason that the figure of the desired candidate is not included in the candidates competing in the election process.

\section{Emotional Closeness}

Emotional closeness also into consideration potential voters to determine the options. Idiologi factor, the origin of the candidates, tribal religious and cultural psychological factors so consideration but the main thing is not to determine the selection. The results of the interview with informen shows that closeness with the figure of the candidate, regional councils into emotional relationship factors that consideration for the public to vote for candidates of mayors and Deputy mayors of Pekanbaru. In addition to regional proximity is also due to the closeness of familial relationships. With the emotional closeness of community assume the selected figures that can pay attention 
to and accommodate the aspirations of the group because there are similarity the origin of the area. Many communities are either not right of vote because emotionally does not recognize the prospective head of the region. Emotional closeness to the most prominent of the research results is the proximity of a tribal culture.

\section{Money politic or transactional politics.}

Money politics could not be avoided in the democracy agenda included the election of the head of the region, although such practices prohibit rules. But the fact is it could not be avoided but difficult proved. This practice reinforced with paradigm woke up in the middle of the community who have voting rights. would choose if it gets in return or the giving of pair candidate of the head area. The results of the interview with informen note that many users are voting rights to transmit vote as it gets something from the candidate, something that could in in the form of money and objects, the bag, clothes and so on. "we chose the person who give us, because once elected they aren't necessarily remember with our" political participation of society very encouraged by the stimulus-stimulus money politics or stimulus-stimulus items. While the things that encourage the occurrence of Money Politics is the factor of education, economic level of society and the low public political awareness. These results are corroborated by the statements of Hungtinton and Nelson stating that some internal factors that encourage the occurrence of money politics, among others, economic deprivation and poverty still afflicting the majority of voters, good living dipedesaan or living in the city. The factors of poverty and the burden of life make the community easily persuaded and influenced especially in determining the granting of several options with money or other material in return.

4. Socialization of execution of the regional head election candidate and socialization.

Socialization of organizing elections of Heads of regions is crucial not only as to the implementation stages of the elections but also the means to let people identify prospective leaders. Socialization can be done by the organizer of the election of the candidate or the head of the region. Many people who say socialization is still lacking so that people do not really recognize the candidate pairs or the programs contained in the vision and mission of each candidate pair. Many people who do not exercise the right to vote do not channel the choice because they never get socialization from the election organizers in this case the Pekanbaru City Electoral Commission. The subsequent lack of sosilasi performed by candidate for Mayor and Deputy Mayor of Pekanbaru. One phase of the general election campaign is District head. This stage can be used to socialize directly to the community and introduce themselves and the program to be implemented if elected in the election. But not all of the campaign schedule followed by the pair of candidates that resulted in a lot of communities don't recognize their leader. Without socialization process of introduction of candidates with konstiuen does not run properly, because among the voters there is also a rational voters look at programs that are contained in the vision and mission of the prospective head of the region. The results of research by conducting interviews with informen can note the lack of socialization can influence the public in choosing a candidate for the head of the region.

\section{CONCLUSION}

Based on the results of discussion and interviews with the author concludes that the factors affecting the tiingkat public participation in the implementation of the election of mayors and Deputy mayors of Soweto is the figure of the candidate. This factor is determined by the satisfaction of society against the incumbent candidate performance and the extent to which the community of voters recognize and understand the candidate's program is not inicumbent. Berilkutnya factor is the emotional closeness with candidates either regional proximity, culture, origin nor the closeness of the relationship. The next factor is money politic or political trasnsaksional. A lot of community voters downloading yalurkan pilihnya rights or aspirations because the granting of candidate. And the last factor is socialization conducted by the organizer of general election of head of region and also socialization conducted by candidate pair of regional head.

\section{REFERENCES}

Djam'an Satori dan Aan Komariah, Metodologi Penelitian Kualitatif, Alfabeta.Bandung, 2010

Gary Yukl, copyright 2001. Kepemimpinan Dalam Organisasi.Jakarta. PT Indeks, 2010

Hadari Nawawi, Metode Penelitian Bidang Sosial, Gadjah Mada University Press, Jogjakarta, 1990

Kacung Marijan, Sistem Politik Indonesia: Konsolidasi Politik Pasca Orde Baru. Jakarta, Prenada Media Grup, 2011

Max Weber dalam bukunya Wirtschaft und Gessellshaft (1992): dalam Miriam Budiardjo, Dasar-Dasar ilmu politik, Jakarta; gramedia Pustaka Utama, 2014

Miriam Budiardjo. Dasar-Dasar ilmu politik, Jakarta; gramedia Pustaka Utama, 2014

Miriam Budiarjdo, Partisipasi dan Partai Politik, Sebuah Bangsa Rampai, Gramedia: Jakarta, 1998

Ndraha, Metodologi Ilmu Pemerintahan, Jakarta, Rineka Cipta, 2010 Rulam Ahmadi, Metode Penelitian Kualitatif. Yogyakarta. Ar-Ruzz Media

Samueh H. Beer dan Adam b. Ulam pattern of government dalam Miriam Budiardjo Dasar-Dasar ilmu politik, Jakarta; gramedia Pustaka Utama 2009

Samuel Huntinton, dan Joan Nelson, Partisipasi Politik di Negara Berkembang. Jakarta Rineka Cipta, 1994 